\title{
Fabrication of iron-cerium mixed oxide: an efficient photocatalyst for dye degradation
}

\author{
Gajendra Kumar Pradhan, K. M. Parida* \\ Colloids and Materials Chemistry Department, Institute of Minerals \& Materials Technology (CSIR), Bhubaneswar-751013, Orissa, INDIA \\ "Corresponding Author: e-mail:paridakulamani@yahoo.com
}

\begin{abstract}
We report herein the fabrication of nanostructured and mesoporous iron-cerium mixed oxides for photocatalytic application. Phase, electronic structure and other properties of the products were characterized by both low-angle and wide-angle X-ray diffraction, diffuse reflectance spectroscopy, transmission electron microscopy, raman spectroscopy, X-ray photoelectron spectroscopy, and $\mathrm{N}_{2}$ adsorption-desorption isotherm methods. Analytical results demonstrate that the catalyst is in the nano order and mesoporous in nature. These samples were screened for photocatalytic degradation of phenol, methylene blue (MB) and congo red (CR). About $13 \%$ (phenol) and $93 \%(\mathrm{MB})$ photodegradation were observed where as complete mineralization was obtained in case of CR. The reason for higher catalytic activity of 1:1 (Fe/Ce) sample is ascribed to their higher surface area, surface acidity which determines the active sites of the catalyst and accelerates the photocatalytic reaction.
\end{abstract}

Keywords: Mixed oxide, photocatalyst, photodegradation.

\section{Introduction}

Energy and environment related topics are considered as thrust areas of today's research. The society is very much conscious about the adverse impacts of various human made industries on the environment. Since a large quantity of dyes were produced as effluents from various textile industries, it is necessary to remove/decompose/degrade these unuseful materials to make them toxic-free (Zollinger, 1991; Galindo et al., 2001). Due to its efficient and cost effective nature; solar-light driven photocatalysis for dye degradation has found widespread applications in various industries. One more advantage of photocatalyis over other existing technology is that there is no requirement of secondary disposal. In this process a photoactive material is required to initiate the catalytic reaction. A lot of work has been done on various photocatalytic materials such as $\mathrm{TiO}_{2}, \mathrm{ZnS}_{2} \mathrm{ZnO}_{2} \mathrm{WO}_{3}, \mathrm{~V}_{2} \mathrm{O}_{5}, \mathrm{CdSe}$, CdS etc (Yoneyama et al., 1979; Hu et al., 2005; Khalil et al., 1998; Li et al., 2006; Harris and Kamat, 2009; Ma et al., 2008 ). Iron oxide having outstanding stability, cost-effectiveness, oxidative power, high resistance to corrosion, and environmentally friendly properties could fulfill many requirement of a good photocatalyst. One more significant advantage of this material is its absorbance in the visible region, which covers $43 \%$ of solar light. However, this semiconductor material has low band gap energy, poor conductivity and high chances for electron-hole $\left(\mathrm{e}^{-}-\mathrm{h}^{+}\right)$recombination, which limit its photocatalytic application. In order to address these issues, many attempts have been made such as incorporation of heteroatom (e.g., Si, Bi, Ti, Mn, Pt and Ta), quantum confinement, and architectural control (Cesar et al., 2006; Luo et al., 2009; Hu et al., 2008; Aroutiouniana et al., 2002; Vayssies et al., 2005).

Ceria is known to be the best material due to its redox behaviour $\left(\mathrm{Ce}^{4+} \leftrightarrow \mathrm{Ce}^{3+}\right)$, oxygen storage capacity (OSC) etc (Dong et al., 2004a). $\mathrm{CeO}_{2}$-based materials have various applications such as three-way catalysts (TWC), fuel cell processes, catalytic wet oxidation, de-SOx catalysis, hybrid-solar cell etc.(Dong et al., 2004b; Sahibzada et al., 1997; Larachi et al., 2002; Trovarelli et al., 1999; Lira-Cantu and Krebs, 2006). Band gap of ceria is $3.1 \mathrm{eV}$ as reported by many researchers which is transparent to the visible light and absorbing only UV light from the solar spectrum where only $5 \%$ solar light is available (Imanaka et al., 2003; Reddy et al., 2009). The mixed oxides systems have the ability to obtain structures in combinations with the properties that neither individual oxide possesses. Coupling of two semiconductors (e.g., CdS/ $/ \mathrm{TiO}_{2}, \mathrm{CdS} / \mathrm{ZnO}, \mathrm{TiO}_{2} / \mathrm{SnO}_{2}, \mathrm{CdSe}_{\mathrm{TiO}}$ ) with suitable energetics can significantly improve the selectivity and enhance the charge separation yield (Jang et al., 2008; Shvalagin et al., 
2007; Liu et al., 2007; Kim et al., 2009). The combination of ceria with $\mathrm{Fe}_{2} \mathrm{O}_{3}$ would be an efficient photocatalyst and will fullfil the seeking property of individual material. To enhance the redox property and thermal stability of pure $\mathrm{CeO}_{2}, \mathrm{Fe}_{2} \mathrm{O}_{3}$ is often mixed as an additive to form mixed oxides (Reddy et al., 2004). Here in, we report the synthesis of iron-cerium mixed oxides by co-precipitation method and evaluated the solar light driven photocatalytic activity towards dyes and phenol degradation. The novelty of synthesis and highly photocatalytic activity of nanosized materials $\left(\mathrm{CeO}_{2}: \mathrm{Fe}_{2} \mathrm{O}_{3}\right)$ are explained with the help of various spectroscopic techniques. To the best of our knowledge, this is the first ever report on fabrication of iron-cerium mixed oxide for photo degradation of phenol, methylene blue, and congo red.

\section{Materials and Methods}

\subsection{Materials}

All the chemicals and reagents are of analytical grade and used without further purification. Iron (III) nitrate nonahydrate, cerium nitrate hexahydate, sodium carbonate, deionised water were used for the sample preparation.

\subsection{Methods}

Pure iron oxide and ceria were prepared by precipitation method where as their mixed oxides were prepared by co-precipitation technique by taking the same precipitating agent, $\mathrm{Na}_{2} \mathrm{CO}_{3}$. All the preparations were performed at room temperature. Iron oxide nanoparticles were prepared according to a method similar to Kudo et al. (2010). In a typical experiment, predetermined quantity of $\mathrm{Fe}\left(\mathrm{NO}_{3}\right)_{3} \cdot 9 \mathrm{H}_{2} \mathrm{O}$ and $\mathrm{Ce}\left(\mathrm{NO}_{3}\right)_{3} \cdot 6 \mathrm{H}_{2} \mathrm{O}$ were taken individually and added to the aqueous solution of $\mathrm{Na}_{2} \mathrm{CO}_{3}$ and were denoted as $100 \mathrm{Fe}, 0 \mathrm{Fe}$ respectively. Mixed oxides were prepared by maintaining the molar ratio of $\mathrm{Fe}\left(\mathrm{NO}_{3}\right)_{3} \cdot 9 \mathrm{H}_{2} \mathrm{O} / \mathrm{Ce}\left(\mathrm{NO}_{3}\right)_{3} \cdot 6 \mathrm{H}_{2} \mathrm{O}$ i.e., $90: 10$ $(90 \mathrm{Fe}), 60: 40(60 \mathrm{Fe}), 50: 50(50 \mathrm{Fe}), 40: 60(40 \mathrm{Fe}), 10: 90(10 \mathrm{Fe})$. The $\mathrm{pH}$ of the above solution was adjusted by the slow addition of $0.25 \mathrm{M}$ of $\mathrm{Na}_{2} \mathrm{CO}_{3}$, which is a slow precipitating agent. After the treatment, the products were collected by filtration, washed several times with deionized water, and dried at $110^{\circ} \mathrm{C}$ for overnight. The dried samples were calcined at $400^{\circ} \mathrm{C}$ for $3 \mathrm{~h}$.

\subsection{Characterization}

2.3.1. X-Ray Diffraction: Powder X-ray diffraction studies were performed to establish the phase purity and crystallinity of all the samples by using Rigaku X-ray diffractometer with $\mathrm{Cu} \mathrm{K} \alpha$ radiation $\left(\lambda=1.54 \mathrm{~A}^{\circ}\right)$ in the $2 \theta$ range from 20 to $70^{\circ}$. Low-angle XRD was done using the same model and scanned in the range from 0 to $10^{\circ}$ to establish the mesoporous structure of the material.

2.3.2. Electron microscopic studies: Surface morphology of the samples was studied through a transmission electronic microscope (TEM) using model FEI, TECNAI G ${ }^{2} 20$, TWIN, Philips operating at $200 \mathrm{kV}$. The samples for electron microscopy were prepared by dispersing in ethanol and coating a very dilute suspension in carbon coated $\mathrm{Cu}$ grids. TEM images were recorded by using Gutan CCD camera.

2.3.3. UV-Vis DRS studies: The optical absorbance was observed by UV-visible diffuse reflectance spectra (Varian, Cary 100). Boric acid was used as the reference.

2.3.4. Raman study: Raman spectra were recorded in a backscattering configuration at room temperature using an RENISHAW InVia Raman spectrometer. An argon ion laser was used as the excitation source and the wavelength was $540 \mathrm{~nm}$.

2.3.5. $\mathrm{N}_{2}$ adsorption-desorption studies: $\mathrm{N}_{2}$ adsorption-desorption studies were performed at $-197{ }^{\circ} \mathrm{C}$ in Automated Surface area and Porosity Analyser (ASAP 2020, Micromeritics, USA). Prior to the analysis, samples were degassed under vacuum $\left(10^{-5}\right.$ torr) at $300{ }^{\circ} \mathrm{C}$ for $4 \mathrm{~h}$.

2.3.6. X-ray photoelectron spectroscopy: The electronic states of $\mathrm{Fe}$ and Ce were examined by X-ray photoelectron spectroscopy (XPS, Kratos Axis 165 with a dual anode ( $\mathrm{Mg}$ and $\mathrm{Al}$ ) apparatus) using the $\mathrm{MgK} \alpha$ source. All the binding energy values were calibrated by using the contaminant carbon $(\mathrm{C} 1 \mathrm{~s}=284.9 \mathrm{eV})$ as a reference. Charge neutralization of $2 \mathrm{eV}$ was used to balance the charge of the sample. Binding energy values of the samples were reproducible within $\pm 0.1 \mathrm{eV}$.

2.3.7. $\mathrm{NH}_{3}$-TPD: TPD was performed to calculate the surface acidity of the sample using CHEMBET-3000 (Quantachrome, USA) instrument in the temperature range of $40-850{ }^{\circ} \mathrm{C}$. About $0.1 \mathrm{~g}$ of powdered sample was contained in a quartz " $\mathrm{U}$ " tube and degassed at $250{ }^{\circ} \mathrm{C}$ for $1 \mathrm{~h}$ with ultra pure nitrogen gas. After cooling the sample to room temperature, for TPD, $\mathrm{NH}_{3}\left(20 \% \mathrm{NH}_{3}\right.$ balanced with helium) gas was flowed through the sample maintaining a heating rate of $10{ }^{\circ} \mathrm{C} / \mathrm{min}$ to record the profile. 


\subsection{Photocatalytic reaction}

The photoefficiency of all synthesized catalysts were tested towards degradation of phenol, congo red, and methylene blue under solar radiation. In a typical experiment, $40 \mathrm{mg}$ catalyst with $20 \mathrm{ml}$ of 10-ppm phenol solution was taken in a $100 \mathrm{ml}$ closed Pyrex flask. The solutions were exposed to sunlight with constant stirring for $4 \mathrm{~h}$. In a similar fashion, $40 \mathrm{mg}$ of catalysts were suspended in $20 \mathrm{ml}$ of $100 \mathrm{ppm} \mathrm{MB}$ and CR solution for photo experiments under identical condition. After irradiation, the suspensions were centrifuged and the concentration of the supernatants were analyzed quantitatively at $504 \mathrm{~nm}\left(\lambda_{\max }\right.$ for phenol), $664 \mathrm{~nm}\left(\lambda_{\max }\right.$ for methylene blue) and $500 \mathrm{~nm}$ ( $\lambda_{\max }$ for congo red) using a Cary-100 (Varian, Australia) spectrophotometer. All the catalytic results were reproducible with $\pm 4 \%$ variation. Total organic carbon (TOC) analysis was performed by ANATOC.

The intensity of solar light was measured using Digital Illuminance Meter (TES-1332A, Taiwan). The sensor was always set in the position of maximum intensity and solar light intensity was measured for every hour between 10:00 and 14:00. The average light intensity was around 100000 lux, which was nearly constant (10AM-2PM) during the experiments.

\section{Results and Discussion}

\subsection{Nucleation and growth of iron-cerium mixed oxides}

Precipitation and co-precipitation methods are simpler and easier technique to prepare nano structure materials. The size of the nanoparticles can be controlled by choosing a suitable precipitating agent. So choice of precipitating agent has a crucial role to design the desired size controlled material. $\mathrm{Na}_{2} \mathrm{CO}_{3}$, a slow precipitating agent was choosen to design the target material. It was observed that the nucleation as well as precipitation starts at $\mathrm{pH}$ range form 3-3.5. The precipitation occurs when the hydrolysis starts with the increasing of $\mathrm{pH}$. Here the $\mathrm{pH}$ was adjusted to 8.2 to get the desired mixed oxide.

\section{2. $X R D$}

The powder X-ray diffraction of all the catalysts calcined at $400{ }^{\circ} \mathrm{C}$ is shown in Figure 1. Crystalline nature of all the materials are confirmed from the diffraction peaks. The observed reflection patterns were assigned either to $\mathrm{Fe}_{2} \mathrm{O}_{3}, \mathrm{or} \mathrm{CeO}_{2}$. The obtained peaks were sharper and intense in case of pure material $(100 \mathrm{Fe}$ and $0 \mathrm{Fe})$ whereas the mixed phase displayed less intense peaks. Both the $\mathrm{Fe}_{2} \mathrm{O}_{3}$ and $\mathrm{CeO}_{2}$ reflection peaks were observed on $90 \mathrm{Fe}, 60 \mathrm{Fe}, 50 \mathrm{Fe}, 40 \mathrm{Fe}, 10 \mathrm{Fe}$ which concludes the formation of mixed phases.

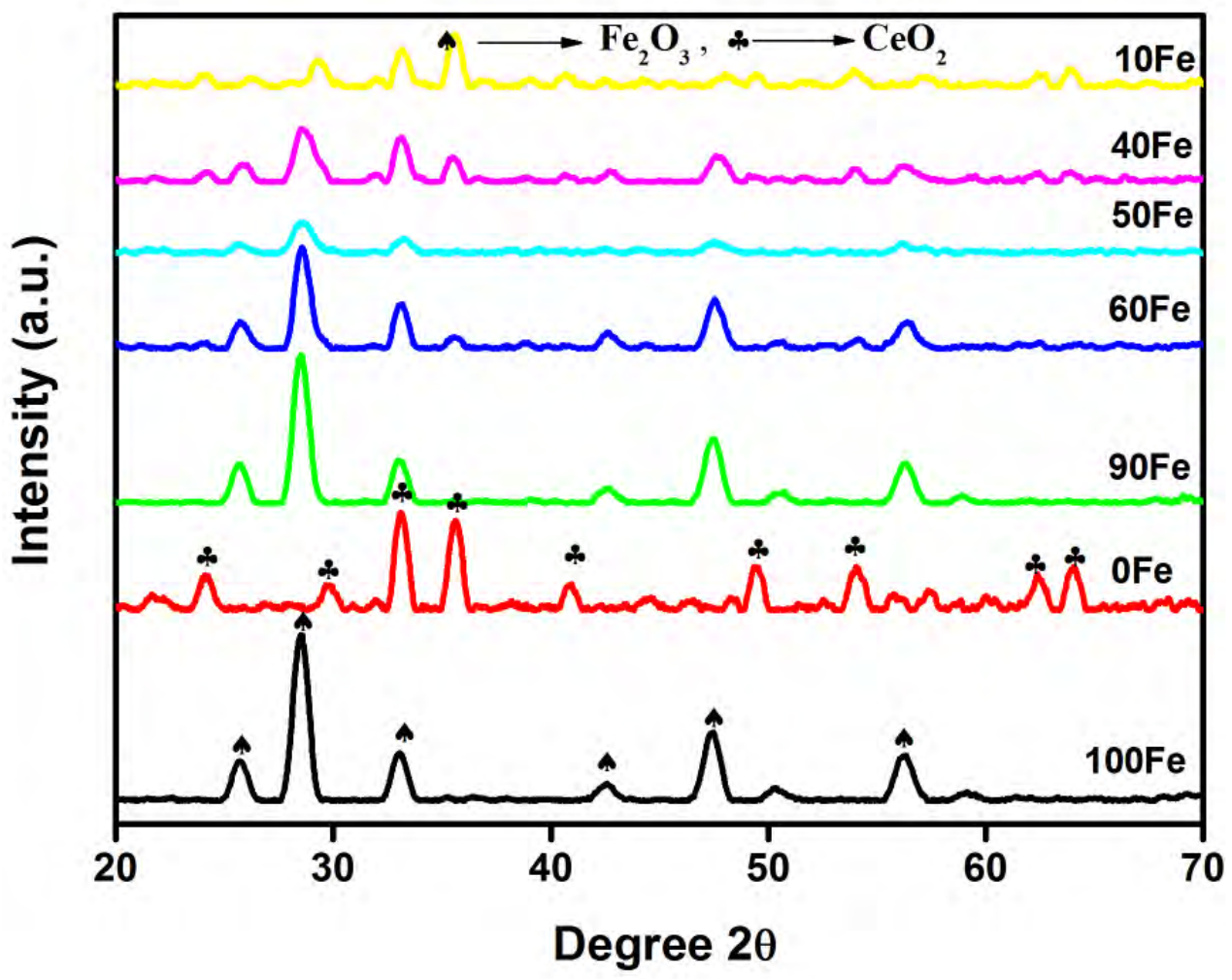

Figure1. X-ray diffraction patterns of $100 \mathrm{Fe}, 90 \mathrm{Fe}, 60 \mathrm{Fe}, 50 \mathrm{Fe}, 40 \mathrm{Fe}, 10 \mathrm{Fe}$ and $0 \mathrm{Fe}$ samples calcined at $400{ }^{0} \mathrm{C}$. 


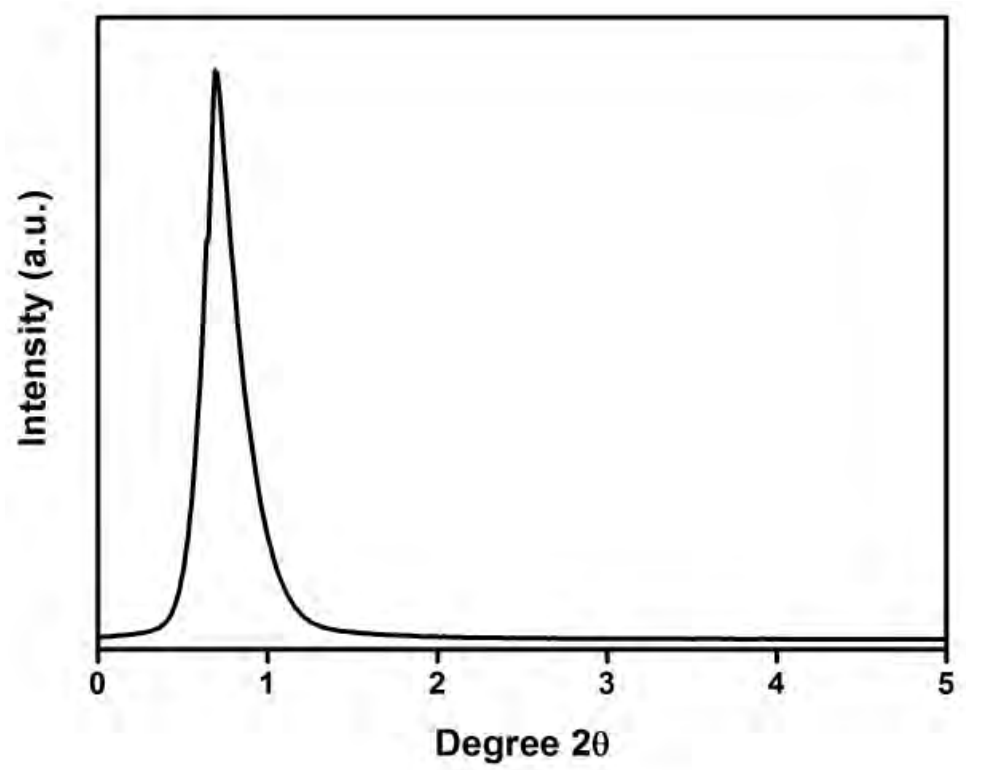

Figure 2. Low angle X-ray diffraction (LAXRD) of sample $50 \mathrm{Fe}$ calcined at $400^{\circ} \mathrm{C}$.

With the increase of both $\mathrm{Ce}$ and $\mathrm{Fe}$ content on the mixed oxide, the diffraction peaks gradually becomes less intense which indicates the development of amorphous nature of the material. In sample 50Fe, the intensity of both $\mathrm{Fe}_{2} \mathrm{O}_{3}$ and $\mathrm{CeO}_{2}$ peak dramatically less intense compared with that of other samples. It can be explained that $\mathrm{CeO}_{2}$ is well dispersed on $\mathrm{Fe}_{2} \mathrm{O}_{3}$ and the amorphous nature is well developed. A diffraction peak appeared for $50 \mathrm{Fe}$ sample at $2 \theta \approx 0.7^{\circ}$ is the characteristic features of mesoporous material (Figure 2).

\subsection{TEM analysis}

TEM analysis of FC5 sample was done to determine the size and morphology of the particles. TEM images, SAED patterns and EDAX were shown in fig. 3(a) and 3(b) respectively. Fig 3 (a) showed the presence of agglomerated nano-sized particles with diameters ranging from 10 to $20 \mathrm{~nm}$. Kaliszewsk et al. claimed that, the material synthesized in the water medium becomes agglomerated due to high capillary forces and hydrogen bonding of water (Kaliszewski and Heuer, 1990; Pati et al., 2009). The agglomeration may be due to the same reason as explained above. From the SAED pattern (inserted in Fig 3b), it is apparent that highly crystalline nanoparticles are obtained. EDAX analysis indicates the presence of all $\mathrm{Fe}, \mathrm{Ce}$ and $\mathrm{O}$ elements.

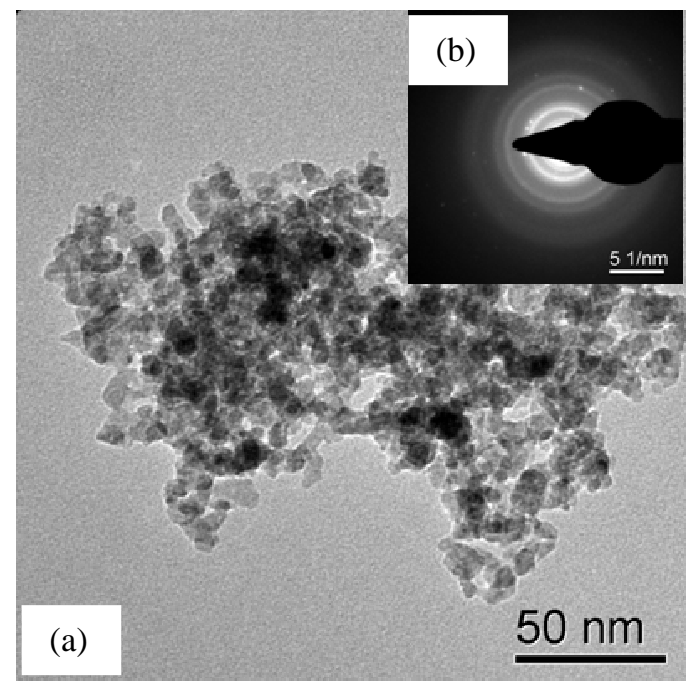

(c)
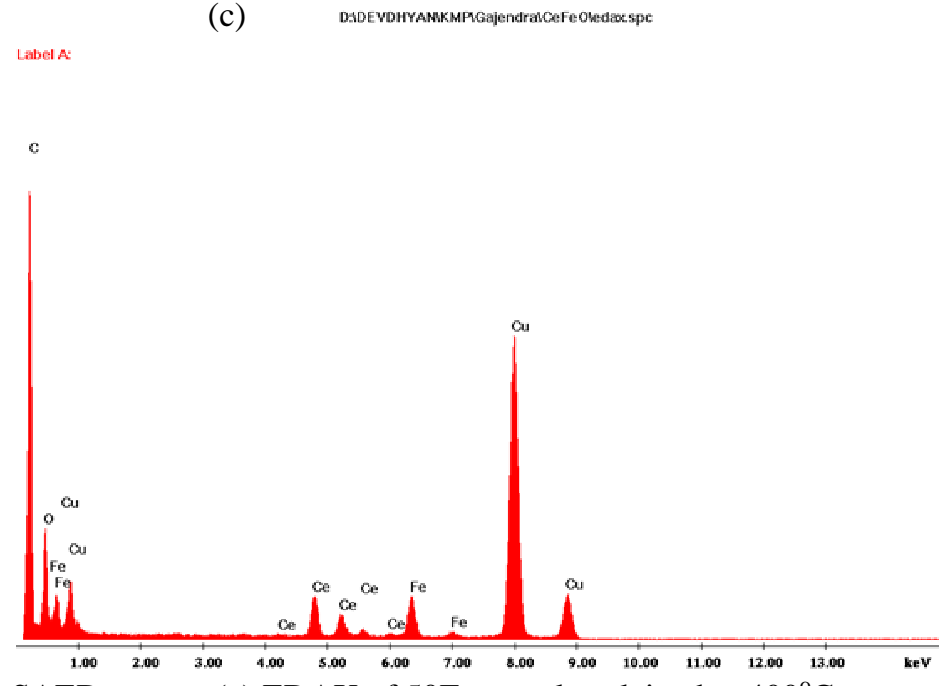

Figure 3. (a) Typical TEM micrograph, (b) SAED pattern (c) EDAX of $50 \mathrm{Fe}$ sample calcined at $400^{\circ} \mathrm{C}$ 


\section{4. $U V$-vis DRS studies}

The optical spectra of all the samples are presented in Figure 4. The band appeared at $342 \mathrm{~nm}$ is designated as the charge transfer spectra of $\mathrm{O}_{2 \mathrm{p}} \rightarrow \mathrm{Ce}_{4 \mathrm{f}}$ of $\mathrm{CeO}_{2}$ (Fangxin et al., 1997). There are two significant peaks observed for $\mathrm{Fe}_{2} \mathrm{O}_{3}$ at 524 and $875 \mathrm{~nm}$. The first is assigned to $2\left({ }^{6} \mathrm{~A}_{1}\right) \rightarrow 2\left({ }^{4} \mathrm{~T}_{1}\right)$ and the later one is due to ${ }^{6} \mathrm{~A}_{1} \rightarrow{ }^{4} \mathrm{~T}_{1}$ transition (Cornell and Schwertmann, 2003). In case of $50 \mathrm{Fe}$, the spectra are quite different from all pure as well as their mixed phase spectra. Also it is in between $\mathrm{CeO}_{2}$ and $\mathrm{Fe}_{2} \mathrm{O}_{3}$ peaks. This suggests that both $\mathrm{Fe}$ and $\mathrm{Ce}$ are incorporated into the oxide matrix and shows unique properties. This is also in good agreement with XRD study.

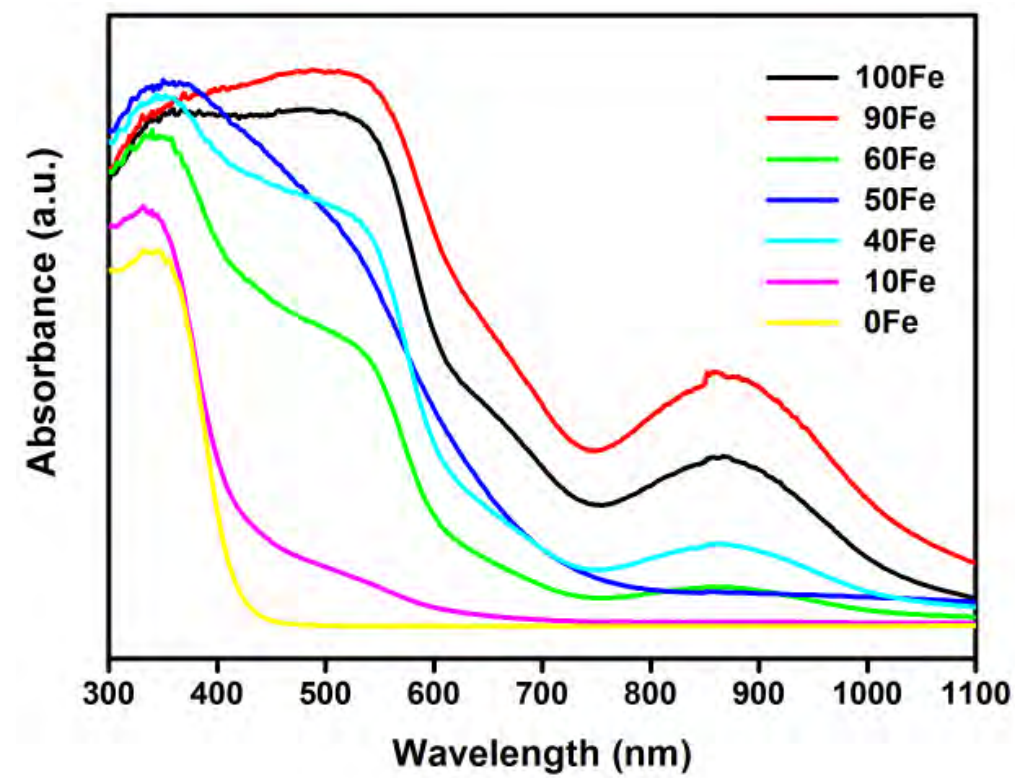

Figure 4. UV-Vis spectrum of samples $100 \mathrm{Fe}, 90 \mathrm{Fe}, 60 \mathrm{Fe}, 50 \mathrm{Fe}, 40 \mathrm{Fe}, 10 \mathrm{Fe}$ and $0 \mathrm{Fe}$ samples calcined at $400{ }^{\circ} \mathrm{C}$

\subsection{Raman spectra study}

The raman spectra of 50Fe sample is depicted in Figure 5. Several Raman active modes were observed for both $\mathrm{Fe}_{2} \mathrm{O}_{3}$ and $\mathrm{CeO}_{2}$. There are two bands appeared for $\mathrm{CeO}_{2}$ at $454 \mathrm{~cm}^{-1}$ and $594 \mathrm{~cm}^{-1}$. According to Weber et al the first peak is due to $\mathrm{F}_{2 \mathrm{~g}}$ mode of the ceria cubic lattice (Weber et al., 1993). Similarly for $\mathrm{Fe}_{2} \mathrm{O}_{3}$, three bands were observed at 282 and $1067 \mathrm{~cm}^{-1}$ for hematite and $713 \mathrm{~cm}^{-1}$ is for maghemite (Leon et al, 2004). Shifting of peaks by some units from their original value of parent material from references, ascertains the formation of mixed oxide between $\mathrm{Fe}_{2} \mathrm{O}_{3}$ and $\mathrm{CeO}_{2}$. The formation of $\mathrm{Fe}_{2} \mathrm{O}_{3}$ and $\mathrm{CeO}_{2}$ is well agreed with the XRD and DRS results.

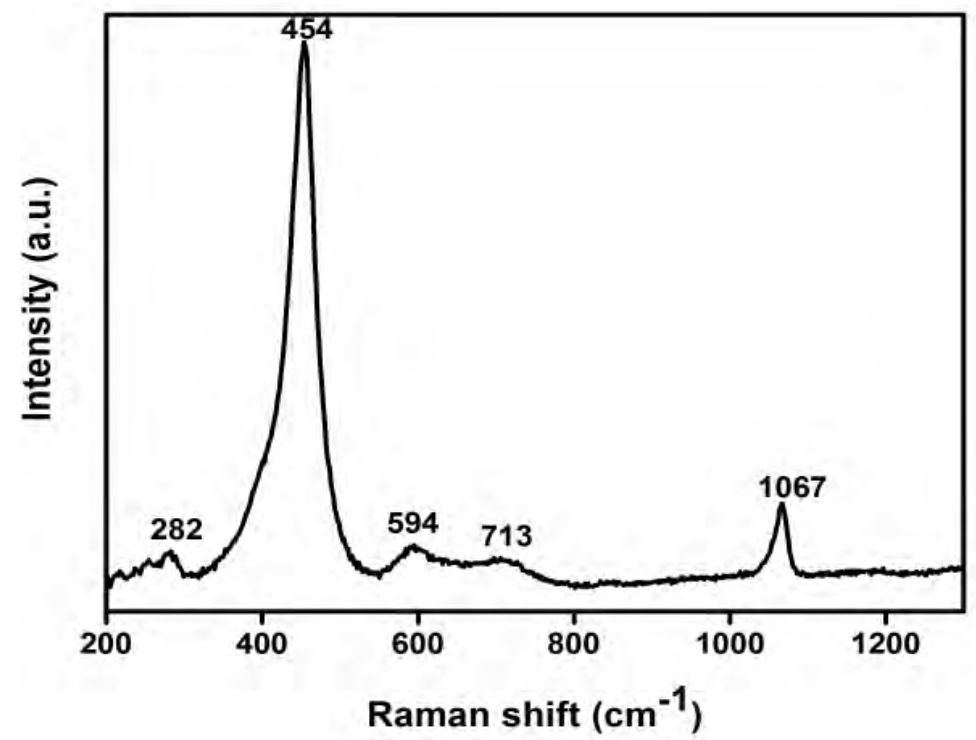

Figure 5. Raman spectrum of 50Fe sample. 


\section{6. $\mathrm{N}_{2}$ adsorption-desorption studies}

The surface areas of all the catalysts are shown in table 1. It is observed that the pure samples have surface area 35.73 (100Fe) and $26.05 \mathrm{~m}^{2} \mathrm{~g}^{-1}(\mathrm{OFe})$. However, the surface area gradually increases with increase of both Ce and Fe content in the case mixed oxides. 50Fe sample having equimolar ratio of $\mathrm{Fe}$ and $\mathrm{Ce}$ shows highest surface area of $94.69 \mathrm{~m}^{2} \mathrm{~g}^{-1}$. The amorphous nature explained in the XRD part strongly affects the surface area of the catalyst. So 50Fe sample having high amorphous character exhibits high surface area compared to others. Figure 6a shows type IV like nitrogen adsorption-desorption isotherms with an inflection of nitrogen-adsorbed volume at $\mathrm{P} / \mathrm{P0}=0.5$ (type $\mathrm{IV}, \mathrm{H}_{2}$ hysteresis loop), indicating the presence of well-developed mesoporosity which is well agreed with the low angle X-ray diffraction data. From the BJH curve (Figure 6b), the pore volume and average pore diameter of $50 \mathrm{Fe}$ catalyst was found to be $0.359 \mathrm{~cm}^{3} \mathrm{~g}^{-1}$ and $15 \mathrm{~nm}$. The pore diameter is in the range of mesoporous which is well agreed with the low angle $\mathrm{X}$-ray diffraction data.

Table.1 Comparison of surface properties of photo catalysts

\begin{tabular}{|r|r|r|}
\hline \multicolumn{1}{|c|}{ Catalyst } & $\begin{array}{c}\text { Surface area } \\
\left(\mathrm{m}^{2} / \mathrm{g}\right)\end{array}$ & $\begin{array}{c}\text { Surface acidity } \\
\left(\mathrm{meq} \mathrm{g}^{-1}\right)\end{array}$ \\
\hline $100 \mathrm{Fe}$ & 35.7 & 0.122 \\
\hline $0 \mathrm{Fe}$ & 26.0 & 0.110 \\
\hline $90 \mathrm{Fe}$ & 27.7 & 0.256 \\
\hline $60 \mathrm{Fe}$ & 45.8 & 0.282 \\
\hline $50 \mathrm{Fe}$ & 94.6 & 0.312 \\
\hline $40 \mathrm{Fe}$ & 42.8 & 0.263 \\
\hline $10 \mathrm{Fe}$ & 31.0 & 0.211 \\
\hline
\end{tabular}

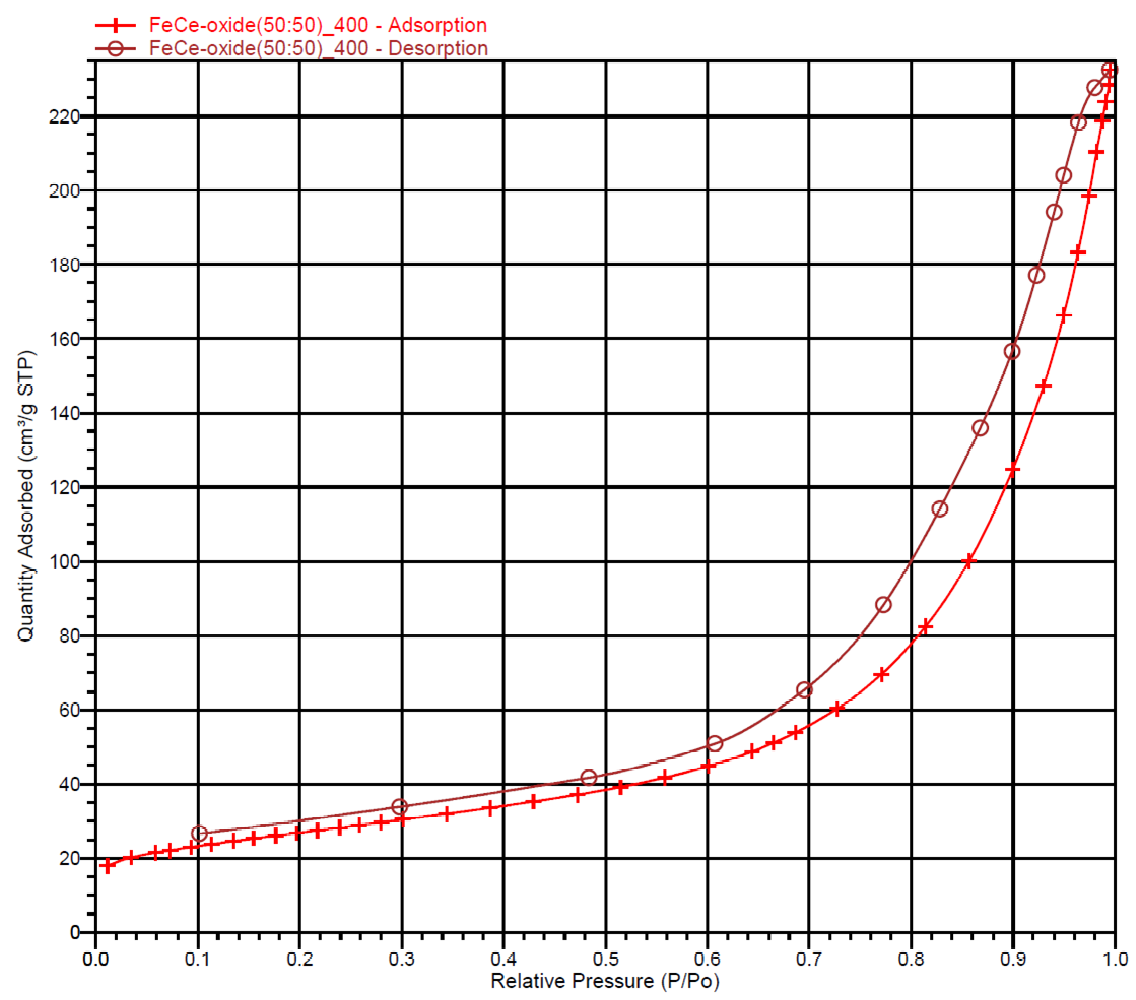

Figure 6a. BET isotherm of sample $50 \mathrm{Fe}$ calcined at $400^{\circ} \mathrm{C}$. 


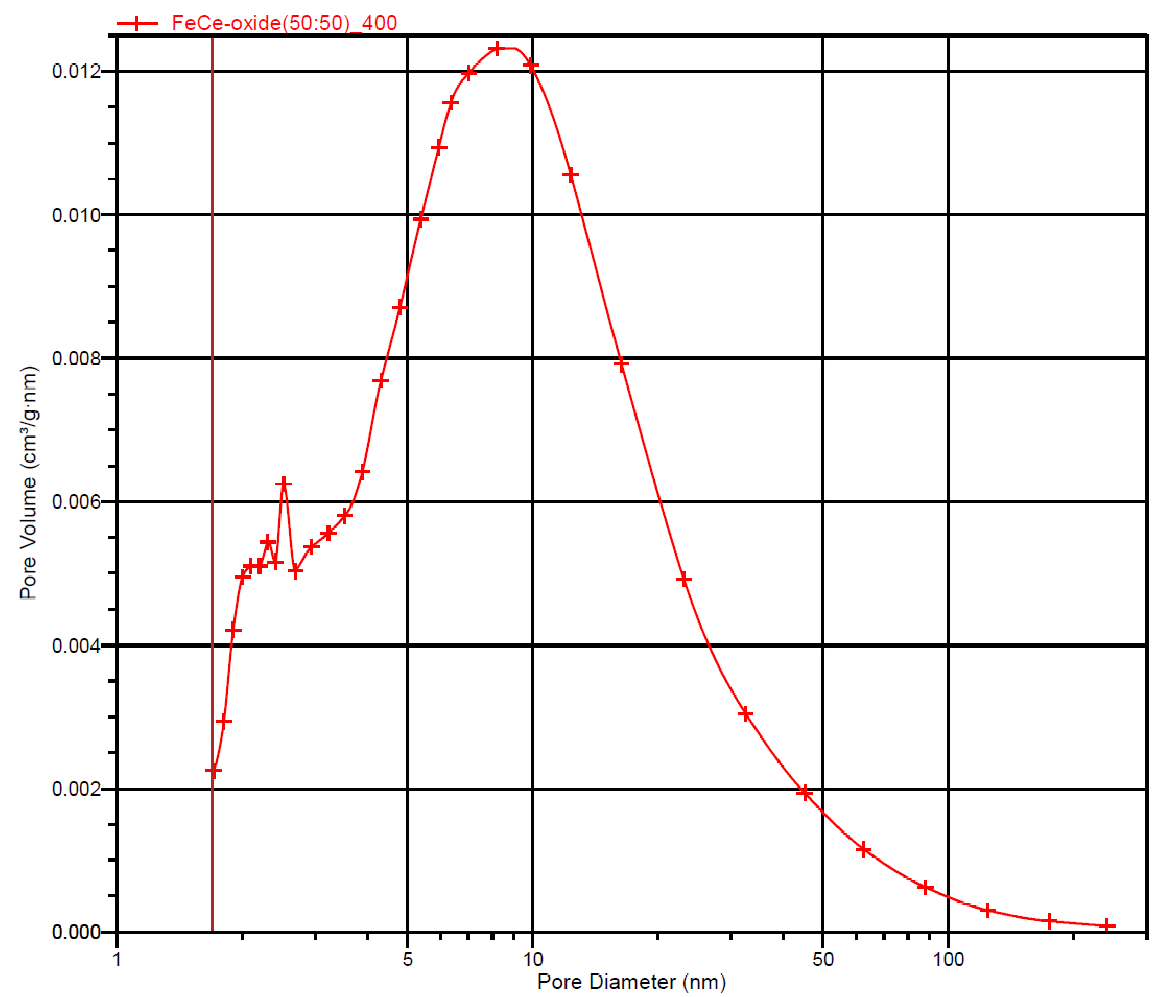

Figure 6b. Pore size distribution curve of $50 \mathrm{Fe}$ sample calcined at $400^{\circ} \mathrm{C}$.

\subsection{X-ray photoelectron spectroscopy}

To know the chemical environment and oxidation states of the elements present in the material, XPS was carried out. The representative photoelectron peaks of $\mathrm{O} 1 \mathrm{~s}, \mathrm{Fe} 2 \mathrm{p}$, and $\mathrm{Ce} 3 \mathrm{~d}$ pertaining to $50 \mathrm{Fe}$ sample are depicted in Figures $7 \mathrm{a}, 7 \mathrm{~b}$ and $7 \mathrm{c}$ respectively. Generally $\mathrm{O}^{2-}$ appeared at $\mathrm{BE}$ value $529.2 \mathrm{eV}$. But in our sample, the O 2p BE peak was observed at $529.4 \mathrm{eV}$ corresponds to $\mathrm{O}^{2-}$.

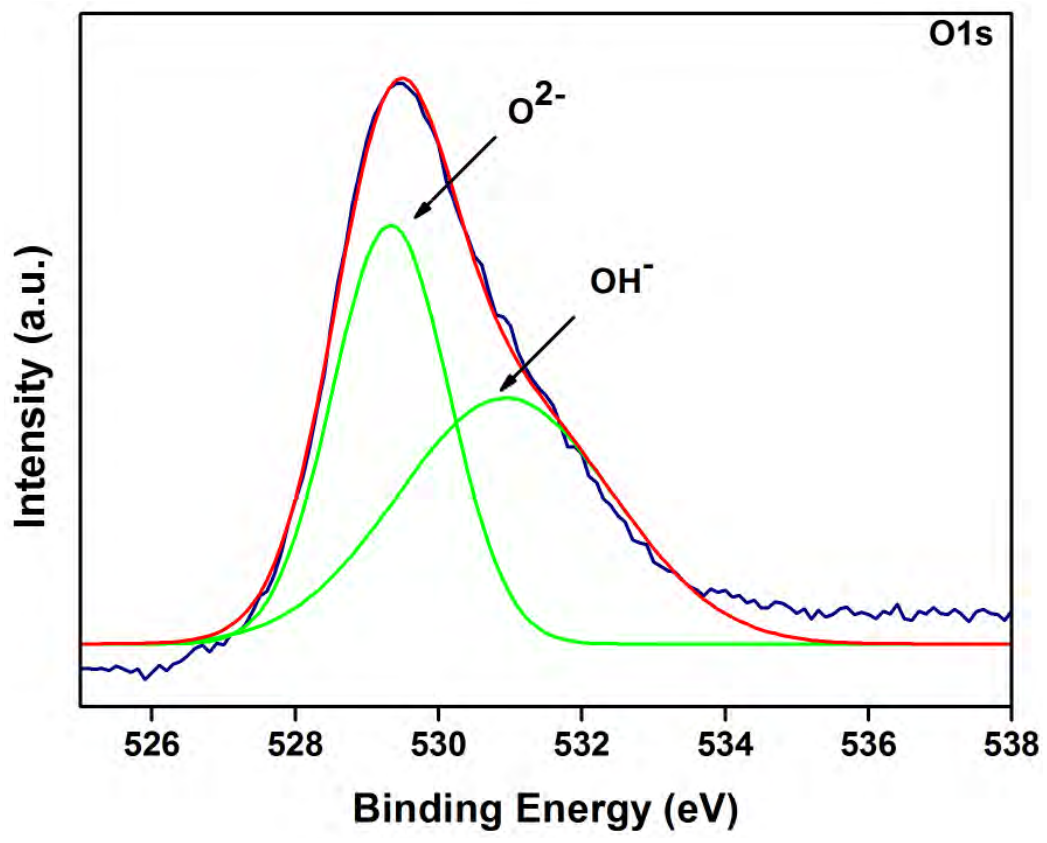

Figure 7(a). 


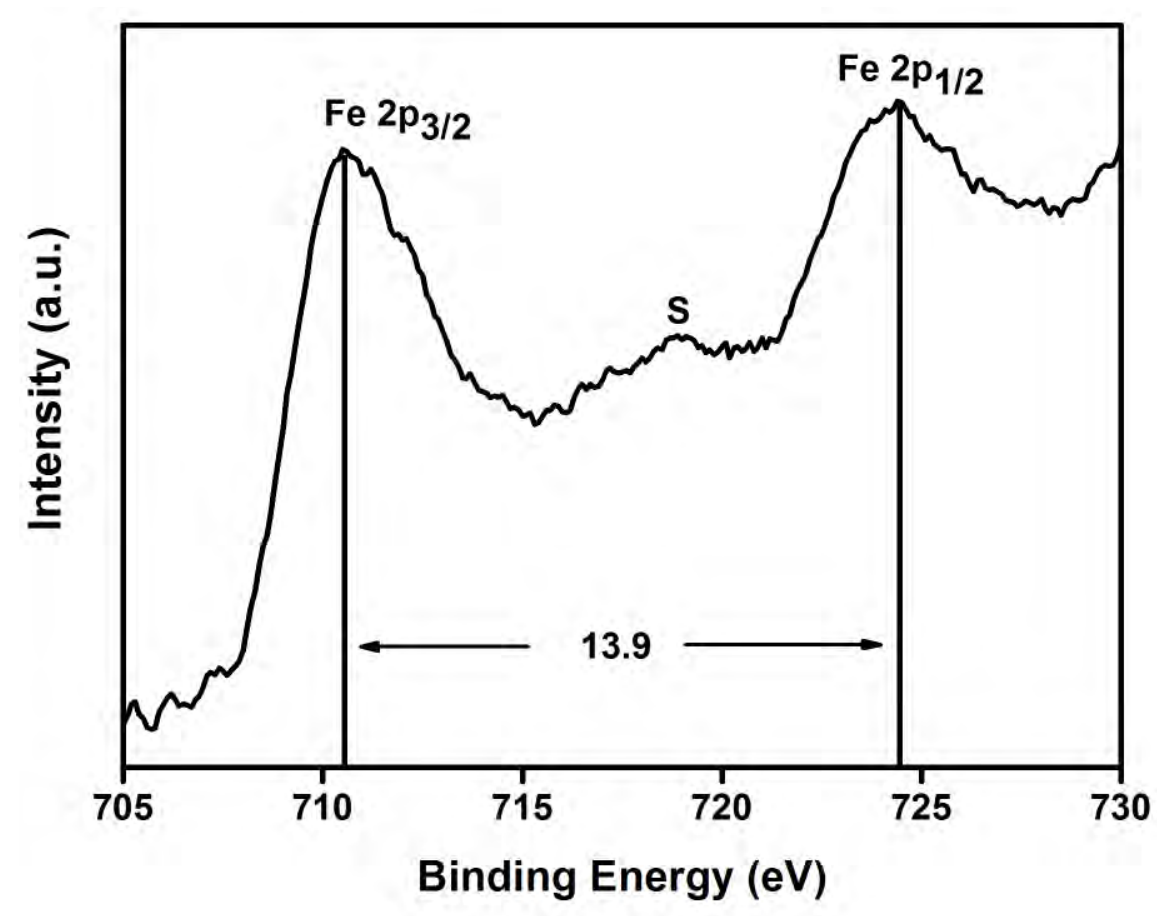

Figure 7(b).

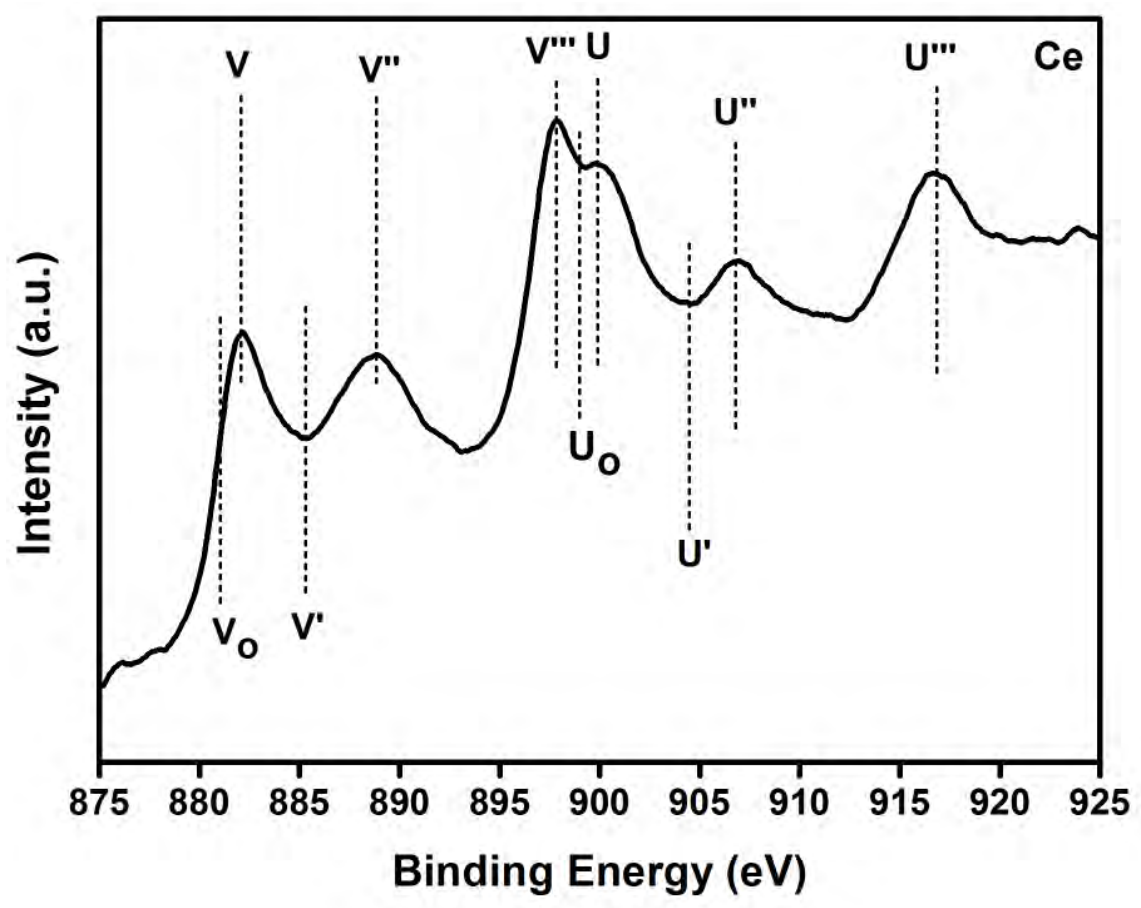

Fig. (7c)

Figure 7. XPS spectra of 50Fe sample (a) High-energy-resolution O 1s core-level spectra (b) High-energy resolution Fe 2p core-level spectra, and (c) High-energy-resolution Ce 3d core-level spectra

There must be some change of electronic environment on $\mathrm{O}^{2-}$ by the coordination with other elements for which the $\mathrm{BE}$ value shifted to higher. A peak at $530.9 \mathrm{eV}$ is assign to surface hydroxyl group $\left(\mathrm{OH}^{-}\right)$(Bhargaba et al., 2007). Generally, $\mathrm{Fe}_{2} \mathrm{O}_{3}$ shows 
two peaks in the region 710.7 and $724 \mathrm{eV}$. But here $2 \mathrm{p}_{3 / 2}$ and $2 \mathrm{p}_{1 / 2}$ peaks were observed at 710.5 and 724.4 respectively. In addition to the above two peaks, a satellite peak is appeared at 718.8 (Yamashita and Hayes, 2008). This confirms the +3 oxidation state of iron in the material. Also no characteristic peaks were found for $\mathrm{Fe}^{0}$ and $\mathrm{Fe}^{2+}$. The peak separation between $2 \mathrm{p}_{3 / 2}$ and $2 \mathrm{p}_{1 / 2}$ is approximately 13.9, which confirms that $\mathrm{Fe}$ is in the oxide phase rather than in metallic form. In the spectrum of Ce $3 \mathrm{~d}$, ten peaks were displayed (Fig.7c). Among them, six peaks corresponding to three pairs of spin-orbit doublets for $\mathrm{Ce}(\mathrm{IV})$ and four peaks corresponding to two pairs of spin-orbit doublets for Ce(III). These peaks were divided into five groups, $\left(\mathrm{v}_{\mathrm{o}}, \mathrm{u}_{\mathrm{o}}\right),(\mathrm{v}, \mathrm{u}),\left(\mathrm{v}^{\prime}, \mathrm{u}^{\prime}\right)$, (v", u") , (v", u"). Conventional designations were assigned to $\mathrm{V}$ and $\mathrm{U}$ of $\mathrm{Ce} 3 \mathrm{~d}_{5 / 2}$ and $3 \mathrm{~d}_{3 / 2}$, respectively (Alonso et al., 2006; Beche et al., 2008; Burroughs et al., 1976). The doublets (v ,u), (v", u”), (v", u”) were assigned to Ce ${ }^{4+}$ whereas $\left(\mathrm{v}_{0}, \mathrm{u}_{\mathrm{o}}\right)$ and $\left(\mathrm{v}^{\prime}\right.$, $\left.\mathrm{u}^{\prime}\right)$ are character of $\mathrm{Ce}^{3+}$. The intensity of XPS peak reflects the quantity of an element. However in our sample, the peaks for $\mathrm{Ce}^{3+}$ is less intense. This confirms that the material is having both $\mathrm{Ce}^{4+}$ and $\mathrm{Ce}^{3+}$ with very minute quantity of $\mathrm{Ce}^{3+}$. Again the peak separation ( $\mathrm{V}$ and $\mathrm{U}$ ) is found to be 18.1 which is nearly equal to peak separation of $\mathrm{CeO}_{2}$ (Wagner et al., 1979; Grosvenor et al., 2004). The peak separation is 3 units higher in case of $\mathrm{Fe}$ spectra from $\mathrm{Fe}_{2} \mathrm{O}_{3}$ where as it is 2 units less than the $\mathrm{Ce}$ of $\mathrm{CeO}_{2}$. This infers that there must be some electronic interaction and synergistic effect between Fe and Ce. The above evidences of formation of both $\mathrm{Fe}-\mathrm{O}$ and $\mathrm{Ce}-\mathrm{O}$ bond as well as the shifting of all $\mathrm{O} 1 \mathrm{~s}, \mathrm{Fe} 2 \mathrm{p}$ and $\mathrm{Ce} 3 \mathrm{~d}$ from its original value confirm the formation of Fe-O-Ce bond.

\section{8. $\mathrm{NH}_{3}-\mathrm{TPD}$}

Surface acidity is one of the key factor which affects the photocatalytic property. $\mathrm{NH}_{3}$-TPD was carried out to determine the surface acidity of all the samples and is depicted in table $1.50 \mathrm{Fe}$ sample shows the highest surface acidity with equal proportion of both the metal content. The charge imbalance in case of mixed oxide is one of the reason for the enhancement of surface acidity compared to single component (Das et al., 2002). This also enhances the photocatalytic activity.

\subsection{Photocatalytic studies}

The photocatalytic mechanism is shown in the scheme: 1 . The degradation of organic dyes mainly occurred by the attack of $\mathrm{OH}$ radical (Zhang et al., 2009). So how these are formed to initiate the degradation mechanism is explained briefly here which is shown in the scheme. Electron and holes are continuously generated when the solar light illuminate on the surface of mixed metal oxide. The metal oxide containing surface hydroxyl group as confirmed from XPS study, directly attacked by the hole to generate the $\mathrm{OH}$ radicals whereas peroxide $\left(\mathrm{O}^{2-}\right)$ is formed when the electron reacts with dissolve oxygen present in the medium (water). This peroxide takes one proton to yield a superoxide $\left(\mathrm{HO}_{2}\right)$ followed by the formation of hydrogen peroxide $\left(\mathrm{H}_{2} \mathrm{O}_{2}\right)$. Hydrogen peroxide again can split to give hydroxide radical and hydroxyl ion.

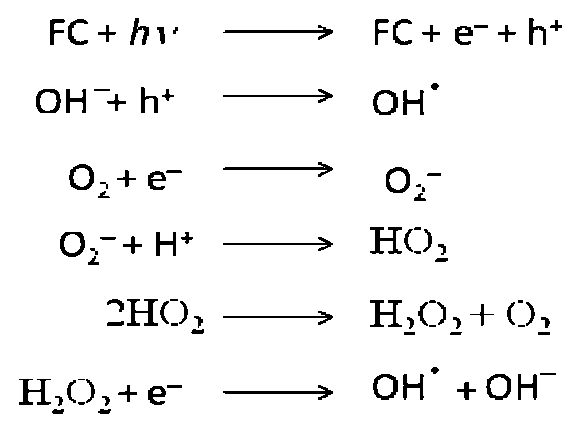

(Scheme: I Schematic illustration of photocatalysis mechanism)

Decolourization of MB and CR were studied in presence of solar light and monitored by UV-vis spectrophotometer. Fig 8 shows the percentage of degradation with the variation of iron to cerium ratio. There are several factors such as carrier recombination, size of the particles, surface area, surface acidity, presence of higher number of hydroxyl group which affects the photocatalytic activity. Pure material $\left(\mathrm{Fe}_{2} \mathrm{O}_{3}\right.$ and $\left.\mathrm{CeO}_{2}\right)$ shows very low percentage of degradation as compared to the mixed phase. However with gradual increase in both metal content, the photocatalytic activity increases and reaches maximum with equal molar ratio of $\mathrm{Fe} / \mathrm{Ce}(50 \mathrm{Fe})$. Ceria and its mixed oxides containing higher percentage of cerium can only utilize UV light (4\% of solar light) for photo degradation of dyes. 


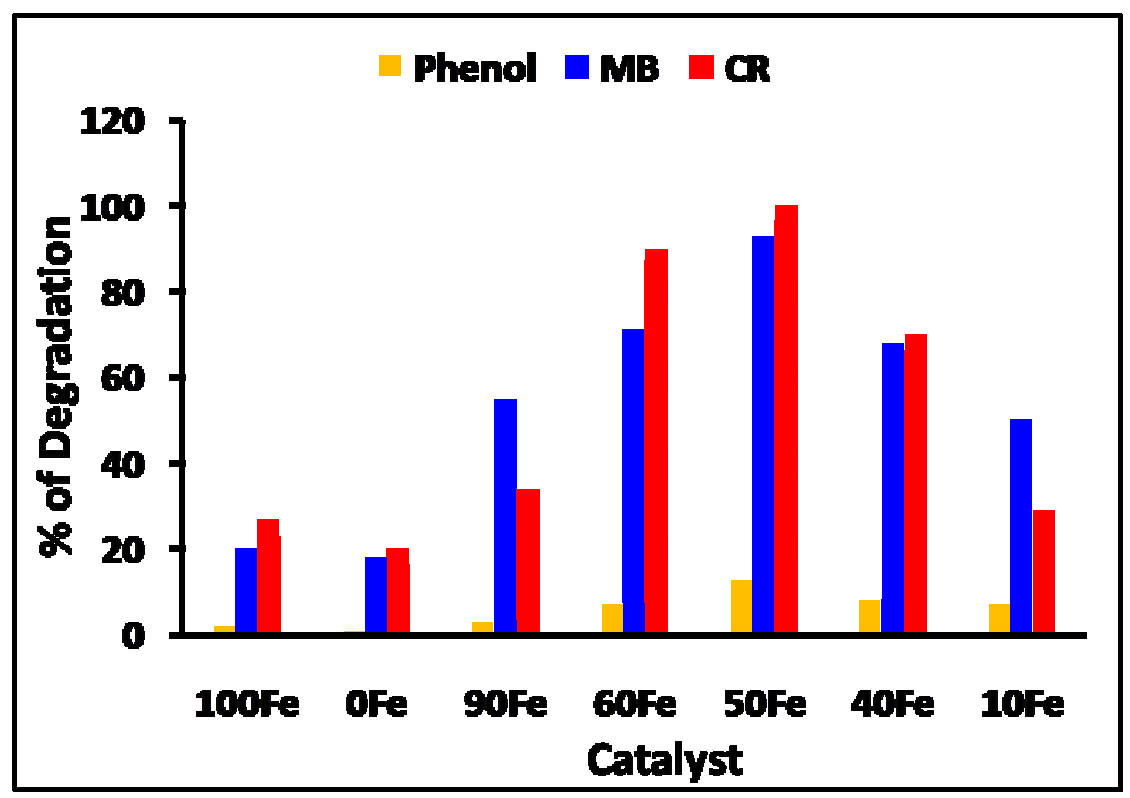

Figure 8. Photocatalytic degradation of Phenol, $\mathrm{MB}$ and $\mathrm{CR}$ over $100 \mathrm{Fe}, 90 \mathrm{Fe}, 60 \mathrm{Fe}, 50 \mathrm{Fe}, \quad 40 \mathrm{Fe}, 10 \mathrm{Fe}$ and $0 \mathrm{Fe}$ catalysts in solar light.

For $\mathrm{Fe}_{2} \mathrm{O}_{3}$, there is a chance of electron-hole recombination where both the charge carriers could not properly involve in the generation of hydroxyl radicals. The same reason can be applied in the higher Fe content catalyst. However when the ratio of cerium and iron is equimolar, the recombination will be minimized as well as the catalyst could absorb maximum solar light from visible region as compared to others. This is why it shows higher percentage of photodegradation. In spite of this, the size of particles is also in the nano order. In case of smaller particle size, both the electron and hole can reach to the catalyst surface within a shorter period as compared to bulk sample after the light illumination. Surface area plays another pivotal role for the activity of a catalyst. Higher the surface area higher will be the surface active sites. Our maximum efficient catalyst (50Fe) has highest surface area as compared to other pure phases as well as their other mixed phases. Although it is not clear that the effect of surface acidity towards the photocatalytic activity, however in our best catalyst $(50 \mathrm{Fe})$ having the highest surface acidity shows the greater degree of degradation.

The maximum degradation of phenol, MB and CR with this catalyst after $4 \mathrm{~h}$ were 13, 93 and $100 \%$ respectively. Figures 9 and

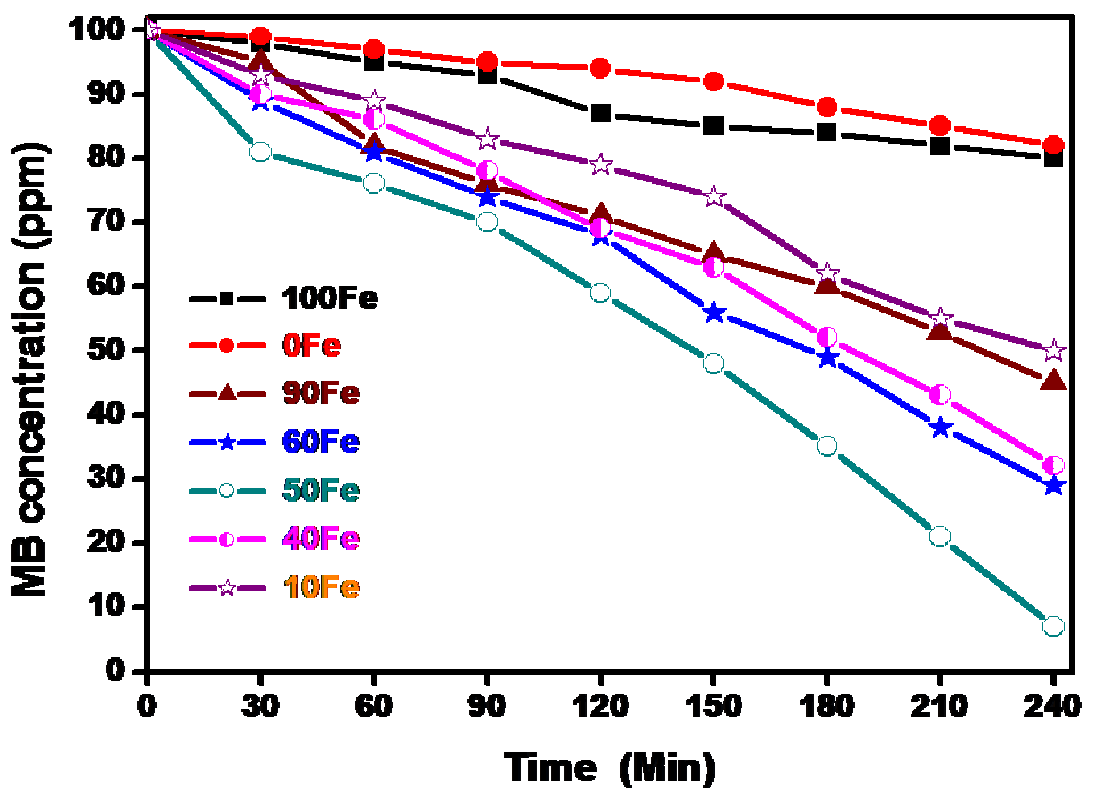

Figure 9. Effect of time over the photodegradation of MB 




Figure 10. Effect of time over the photo degradation of CR

10 show the time dependent photodegradation of MB and CR. In this part, we have studied the decolorization behaviour in each 30 minutes interval. With increase of degradation time, the $\%$ of degradation is increasing. In case of $\mathrm{MB}$, the maximum degradation obtained after $4 \mathrm{~h}$ is $93 \%$ whereas it is $100 \%$ for CR.

TOC was performed to know how much percentage of organic carbon converted to $\mathrm{CO}_{2}$. The percentage of total organic carbon removal was found to be 9,77 , and $85 \%$ for phenol, $\mathrm{MB}$, and CR respectively, after $4 \mathrm{~h}$ of reaction over $50 \mathrm{Fe}$ catalyst.

\section{Conclusions}

The following conclusions are drawn from the present studies:

1. The paper highlights for the first time the synthesis of mesoprous and nano structured iron-cerium mixed oxides for photodegradation of phenol, methylene blue and Congo red by direct illuminating to sun light.

2. A mixed phase of two opposite character catalyst compensate with the synergistic effect to become an efficient photo catalysts.

3. XRD, UV-vis DRS, Raman, XPS revealed the formation of mixed oxide.

4. Mesoporosity was confirmed from both LAXRD and BJH isotherm.

5. TEM evidenced the nano nature of the particles.

6. 50Fe catalyst with 50:50 content of both $\mathrm{Fe}$ and $\mathrm{Ce}$ acted as an efficient catalyst when compared to others and showed highest percentage of degradation over all the tested dyes.

\section{References}

Alonso FJ P., Granados ML., Ojeda M., Herranz T., Rojas S., Terreros P., Fierro JLG., Gracia M and Gancedo JR., 2006. Relevance in the Fischer-Tropsch synthesis of the formation of fe-O-ce interactions on iron-cerium mixed oxide systems. $J$. Phys. Chem. B, Vol.110, pp.23870-23880.

Aroutiouniana VM., Arakelyana VM., Shahnazaryana GE., Stepanyana GM., Turnerb JA and Khaselev O., 2002. Investigation of ceramic $\mathrm{Fe}_{2} \mathrm{O}_{3}\langle\mathrm{Ta}$ photoelectrodes for solar energy photoelectrochemical converters. International Journal of Hydrogen Energy, Vol.27, pp. 33-38.

Beche E., Charvin P., Perarnau, D., Abanades, S., Flamant, Gilles., 2008. Ce 3d XPS investigation of cerium oxides and mixed cerium oxide $\left(\mathrm{Ce}_{x} \mathrm{Ti}_{y} \mathrm{O}_{z}\right)$. Surf. Interface Anal., Vol 40, pp.264-267. 
Bhargava G., Gouzman I., Chun CM., Ramanarayanan TA., Bernasek SL.,2007. Characterization of the "native" surface thin film on pure polycrystalline iron: A high resolution XPS and TEM study. Appl. Surf. Sci., Vol.253, pp.4322-4329.

Burroughs P., Hamnett A., Orchard AF and Thornton G., 1976. Satellite structure in the $X$-ray photoelectron spectra of some binary and mixed oxides of lanthanum and cerium. J. Chem. Soc. Dalton Trans, pp.1686-1698.

Cesar I., Kay, A., Martinez J. A. G., Gratzel M., 2006. Translucent Thin Film $\mathrm{Fe}_{2} \mathrm{O}_{3}$ photoanodes for efficient water splitting by sunlight: nanostructure-directing effect of Si-doping. J. Am. Chem. Soc., Vol.128, pp. 4582-4583.

Cornell R. M., Schwertmann U., 2003. The iron oxide book, Second Edition, pp.147.

Das D., Mishra H.K., Parida K.M., Dalai,A.K., 2002. Preparation, physico-chemical characterization and catalytic activity of sulphated $\mathrm{ZrO}_{2}-\mathrm{TiO}_{2}$ mixed oxides. J. Mol. Catal. A: Chemical, Vol. 189, pp. 271-282.

Dong F., Suda, A., Tanabe T., Y. Nagai Sobukawa H., Shinjoh H., Sugiura M., Descorme C., Duprez D., $2004 a$. Characterization of the dynamic oxygen migration over $\mathrm{Pt} / \mathrm{CeO}_{2}-\mathrm{ZrO}_{2}$ catalysts by ${ }^{18} \mathrm{O} /{ }^{16} \mathrm{O}$ isotopic exchange reaction. Catal. Today, Vol. 90, pp. 223-229.

Dong F., Suda A., Tanabe T., Nagai Y., Sobukawa H., Shinjoh H., Sugiura M., Descorme C., Duprez D., 2004b. Dynamic oxygen mobility and a new insight into the role of $\mathrm{Zr}$ atoms in three-way catalysts of $\mathrm{Pt} / \mathrm{CeO}_{2}-\mathrm{ZrO}_{2}$. Catal. Today, Vol. 93-95, pp. $827-832$.

Fangxin L., Chengyun W., Qingde S., Tianpeng Z., Guiwen Z.,1997. Optical properties of nanocrystalline ceria. Appl. Opt., Vol. 36, pp. 2796-2798.

Galindo C., Jacques P., Kalt A., 2001. Photooxidation of the phenylazonaphthol AO20 on $\mathrm{TIO}_{2}$ : kinetic and mechanistic investigations. Chemosphere, Vol.45, pp. 997-1005.

Grosvenor A. P., Kobe B. A., Biesinger M. C., Mclntyre N. S., 2004. Investigation of multiplet splitting of Fe 2p XPS spectra and bonding in iron compounds. Surf. Interface Anal., Vol.36, pp.1564-1574.

Harris C., Kamat P. V., 2009. Photocatalysis with CdSe nanoparticles in confined media: mapping charge transfer events in the subpicosecond to second time scales. ACS nano., Vol.3, pp.682-690.

Hu J. S., Ren L.L., Guo Y. G., Liang H. P., Cao A. M., Wan L. J., Ba C. L., 2005. Mass production and high photocatalytic activity of ZnS nanoporous nanoparticles. Angew. Chem. Int. Ed., Vol. 44, pp.1269-1273.

Hu Y. S., Shwarsctein A. K., Forman A. J., Hazen D., Park J. N., McFarland E. W., 2008. Pt-doped $\alpha-\mathrm{Fe}_{2} \mathrm{O}_{3}$ thin films active for photoelectrochemical water splitting. Chem. Mater., Vol. 20, pp. 3803-3805.

Imanaka N., Masui T., Hirai H., Adachi G., 2003. Amorphous cerium titanium solid solution phosphate as a novel family of band gap tunable sunscreen materials. Chem. Mater., Vol.15, pp. 2289-2291.

Jang J. S., Choi S. H., Kim H. G., Lee J. S., 2008. Location and state of $\mathrm{Pt}$ in platinised $\mathrm{CdS} / \mathrm{TiO}_{2}$ photocatalysts for hydrogen production from water under visible light. J. Phys. Chem. C., Vol. 112, pp.17200-17205.

Kaliszewski M. S., Heuer A. H., 1990, Alcohol Interaction with Zirconia Powders. J. Am. Ceram. Soc., Vol.73, pp.1504-1509.

Kim J. Y., Choi S. B., Noh J. H., Yoon S. H., Lee S., Noh T. H., Frank A. J., Hong K. S., 2009. Synthesis of CdSe-TiO nanocomposites and their applications to $\mathrm{TiO}_{2}$ sensitized solar cells. Langmuir, Vol. 25, pp.5348-5351.

Khalil L.B., Mourad W. E. Rophae M. W., 1998. Photocatalytic reduction of environmental pollutant $\mathrm{Cr}(\mathrm{VI})$ over some semiconductors under UV/visible light illumination. Appl. Catal. B: Environ., Vol. 17, pp.267-273.

Kudo S., Maki T., Yamada M., Mae K., 2010, A new preparation method of Au/ferric oxide catalyst for low temperature CO oxidation. Chem Eng. Sc., Vol. 65, pp.214-219.

Larachi F., Pierre J., Adnot A., Bernis A., 2002. Ce 3d XPS study of composite CexMn $\mathrm{Mn}_{1-\mathrm{x}} \mathrm{O}_{2-\mathrm{y}}$ wet oxidation catalysts. Appl. Surf. Sci., Vol.195, pp.236-250.

Leon C. P., Kador L., Zhang M., Muller A. H. E., 2004. In situ laser-induced formation of $\alpha-\mathrm{Fe}_{2} \mathrm{O}_{3}$ from $\mathrm{Fe}^{3+}$ ions in a cylindrical core-shell polymer brush. J. Raman Spectrosc., Vol. 35, pp.165-169.

Li B., Xu Y., Rong G., Jing M., Xie Y., 2006. Vanadium pentoxide nanobelts and nanorolls : from controllable synthesis to investigation of their electrochemical properties and photocatalytic activities. Nanotechnology., Vol.17, pp.2560-2566.

Lira-Cantu M. and Krebs F. C., 2006. Hybrid solar cells based on MEH-PPV and thin film semiconductor oxides $\left(\mathrm{TiO}_{2}, \mathrm{Nb}_{2} \mathrm{O}_{5}\right.$, $\mathrm{ZnO}, \mathrm{CeO}_{2}$ and $\mathrm{CeO}_{2}-\mathrm{TiO}_{2}$ ): Performance improvement during long-time irradiation. Solar Energy Mater. Solar Cells., Vol. 90, pp.2076-2086.

Liu Z., Sun D. D., Guo Peng., Leckie J. O., 2007. An efficient bicomponent $\mathrm{TiO}_{2} / \mathrm{SnO}_{2}$ nanofiber photocatalyst fabricated by electrospinning with a side-by-side dual spinneret method. Nano Lett., Vol. 7, pp.1081-1085.

Luo W., Wang D., Wang F., Liu T., Cai J., Zhang L., Liu Y., 2009, Room-temperature simultaneously enhanced magnetization and electric polarization in $\mathrm{BiFeO}_{3}$ ceramic synthesized by magnetic annealing. Appl. Phys. Lett., Vol. 94, pp.202507.

Ma L. L., Sun H. Z., Zhang Y. G., Lin Y. L., Li J. L., Wang E., Yu Y., Tan M., Wang J. B., 2008. Preparation, characterization and photocatalytic properties of CdS nanoparticles dotted on the surface of carbon nanotubes. Nanotechnology., Vol.19,pp. 115709.

Pati R. K., Lee I. C., Gaskell K. J., Ehrman S. H., 2009. Precipitation of nanocrystalline $\mathrm{CeO}_{2}$ using triethanolamine. Langmuir, Vol.25, pp.67-70.

Reddy B. M., Lakshmanan P., Khan A., 2004. Investigation of Surface Structures of Dispersed $\mathrm{V}_{2} \mathrm{O}_{5}$ on $\mathrm{CeO}_{2}-\mathrm{SiO}_{2}, \mathrm{CeO}_{2}-\mathrm{TiO}_{2}$, and $\mathrm{CeO}_{2}-\mathrm{ZrO}_{2}$ Mixed Oxides by XRD, Raman, and XPS Techniques. J. Phys. Chem. B., Vol.108, pp. 16855-16863. 
Reddy J. K., Srinivas B., Kumari V. D., Subrahmanyam M., 2009. $\mathrm{Sm}^{3+}$-doped $\mathrm{Bi}_{2} \mathrm{O}_{3}$ photocatalyst prepared by hydrothermal synthesis. Chem. Cat. Chem., Vol.1, pp.492 - 496.

Sahibzada M., Steele B. C. H., Zheng K., Rudkin R. A., Metcalfe I. S., 1997. Development of solid oxide fuel cells based on a $\mathrm{Ce}(\mathrm{Gd}) \mathrm{O}_{2^{-} \mathrm{x}}$ electrolyte film for intermediate temperature operation. Catal. Today., Vol. 38, pp.459-466.

Shvalagin V. V., Stroyuk A. L., Kotenko I. E., Kuchmii S. Y., 2007. Photocatalytic formation of porous CdS/ZnO nanospheres and CdS nanotubes. Theor. and Experim. Chemi., Vol.43, pp.229-234.

Trovarelli A., Leitenburg D. C., Boaro M., Dolcetti G., 1999. The utilization of ceria in industrial catalysis. Catal. Today., Vol. 50, pp.353-367.

Vayssies L., Sathe C., Butorin S. M., Shuh D. K., Nordgren J., Guo J., 2005. One-dimensional quantum-confinement effect in $\alpha$ $\mathrm{Fe}_{2} \mathrm{O}_{3}$ ultrafine nanorod arrays. Adv. Mater., Vol. 17, pp.2320-2323.

Wagner C. D., Riggs W. M., Davis L. E., Muilenberg J. F., 1979. Handbook of X-ray Photoelectron Spectroscopy, Perkin Elmer.

Weber W. H., Hass K.C., McBride J. R., 1993. Raman study of $\mathrm{CeO}_{2}$ : second-order scattering, lattice dynamics, and particle-size effects. Physical Review B., Vol. 48, pp.178-185.

Yamashita T., Hayes P., 2008. Analysis of XPS spectra of $\mathrm{Fe}^{2+}$ and $\mathrm{Fe}^{3+}$ ions in oxide materials. Appl. Surf. Sci., Vol.254, pp.2441-2449.

Yoneyama H. Yamashita Y., Tamura H., 1979. Heterogeneous photocatalytic reduction of dichromate on n-type semiconductor catalysts. Nature., Vol. 282, pp.817-818.

Zhang L.S., Wong K. H., Zhang D. Q., Hu C., Yu J. C., Chan C. Y., Wong P. K., 2009. Zn:In(OH)ySz solid solution nanoplates: synthesis, characterization, and photocatalytic mechanism. Environ. Sci. Technol., Vol. 43, pp.7883-7888.

Zollinger H., 1991. Color chemistry: synthesis properties and applications of organicsdyes and pigments, 2nd revised ed. VCH, Weinheim.

\section{Biographical notes}

Mr. Gajendra Kumar Pradhan is working as Senior research fellow in Colloids and Materials Chemistry Department, Institute of Minerals and Material Technology, Bhubaneswar (India). He has engaged research since last 4 years. His research interest is fabrication of different shape and size controlled nanoparticles for catalytic application. Mr. G. K. Pradhan has published three papers in various international journals.

Dr. Kulamani Parida, Scientist-G and Head, Colloids and Materials Chemistry Department, Institute of Minerals and Material Technology, Bhubaneswar (India). His field of research is on fabrication of different materials in general and photocatalytic materials in particular, their characterization and catalytic application. He has more than 170 publications in national and international journals.

Received August 2010

Accepted October 2010

Final acceptance in revised form October 2010 